\title{
Development of leucaena mimosine-degrading bacteria in the rumen of sheep in Myanmar
}

\author{
AUNG AUNG, MOE THIDA HTUN, LWIN NAING OO, MAR MAR KYI AND TIN NGWE \\ Department of Physiology and Biochemistry, University of Veterinary Science, Yezin, Nay Pyi Taw, Myanmar.
}

Keywords: Leucaena leucocephala, anti-nutritive factor, toxicity symptoms, urinary concentration.

\section{Introduction}

Myanmar has an agricultural base, and about $70 \%$ of people reside in rural areas. They depend for survival on agriculture and small-scale crop production, with ruminant livestock consuming fibrous agricultural residues. For optimal ruminant production, concentrates are needed as supplements to these residues. As concentrates are expensive, researchers are testing alternative protein sources like legumes, including foliage from leguminous trees such as leucaena (Leucaena leucocephala). Leucaena is the most widely used leguminous tree as a ruminant feed because it is rich in protein $(\sim 22 \%)$ and contains easily digestible fiber $(23 \%$ neutral detergent fiber, $16.6 \%$ acid detergent fiber; Ni Ni Maw 2004). Khin Htay Myint (2005) noted that 25\% of leucaena in the ration tended to increase nitrogen retention without decreasing dry matter and organic matter digestibilities.

However, leucaena leaves contain a toxic non-protein amino acid, called mimosine. Research workers have endeavored to reduce mimosine toxicity in animals fed leucaena in Myanmar (Aung Aung 2007; Wink Phyo Thu 2010) and one avenue of research was the development of mimosine-degrading bacteria in the rumen of sheep fed leucaena. In this paper we describe an experiment tracing the development of mimosine-degrading bacteria in the rumen of sheep.

\section{Materials and Methods}

The experiment was carried out using 9 male sheep aged 6-8 months and weighing $11-18 \mathrm{~kg}$. The animals were divided into 3 groups and fed the following 3 diets: rice straw + mixed concentrate $(\mathrm{G} 1)$; rice straw + mixed concentrate $+50 \%$ leucaena leaves $(\mathrm{G} 2)$; and rice straw

Correspondence: Aung Aung, Department of Physiology and Biochemistry, University of Veterinary Science, Yezin, 05282, Nay Pyi Taw, Myanmar.

Email: aung.aaung@gmail.com
+ mixed concentrate + gradually increased amount of leucaena leaves from $10 \%$ to $50 \%$ level (4 days for each level) (G3). Body temperatures of sheep were measured daily, when the animals were checked for clinical signs and symptoms of mimosine toxicity. Mimosine concentration in urine was determined at the end of the experiment.

\section{Results}

Results of clinical examinations and urinary mimosine concentrations of sheep after feeding 50\% leucaena leaf are shown in Table 1. Animals from all groups had the same average body temperature $\left(37.5^{\circ} \mathrm{C}\right)$. Clinical signs appeared 4 days after feeding 50\% leucaena in the total diet for animals in G2. The most prominent signs were hair loss, dullness and decrease in feed intake. However, no clinical signs of leucaena mimosine toxicosis were observed in animals from G3 throughout the experimental period, although urinary mimosine levels in this group were high.

\section{Discussion}

The loss of hair by animals from the group fed $50 \%$ leucaena after 4 days from the start of feeding is similar to the reports of Hegarty et al. (1964). Toxic symptoms in cattle were reported by other research workers (Jones and Hegarty 1984). The failure of toxicity to alter body temperature of the sheep agrees with the experiment of Jones et al. (1978), where rectal temperature of all cattle showing toxic symptoms was normal. However, in the experiment of Hegarty et al. (1964), the body temperature of sheep was $105^{\circ} \mathrm{F}\left(40.6^{\circ} \mathrm{C}\right)$ after 4 days of infusion of mimosine and higher than that of sheep from this experiment. The absence of toxic symptoms when the animals were fed on gradually increased amount of leucaena leaves was unexpected, as mimosine levels in urine of this group were high. Molecular identification of bacterial strains from rumen liquor will be performed to check the possibility that mimosine-degrading strains 
were present. Subsequently, rumen liquor from the sheep which developed the ability to degrade mimosine will be transferred to other ruminants to encourage more extensive use of leucaena in Myanmar.

Table 1. Clinical examination of sheep with and without leucaena in the diet.

\begin{tabular}{lllll}
\hline \multirow{2}{*}{ Group $^{1}$} & \multicolumn{3}{c}{ Clinical signs } \\
\cline { 2 - 5 } & $\begin{array}{l}\text { Body } \\
\text { temperature }\left({ }^{\circ} \mathrm{C}\right)\end{array}$ & $\begin{array}{l}\text { Loss of } \\
\text { weight }\end{array}$ & Hair loss & $\begin{array}{l}\text { Urinary mimosine } \\
(\mathrm{mg} / \mathrm{L})\end{array}$ \\
\hline 1 & 37.5 & Nil & Nil & 0 \\
2 & 37.5 & Slightly & Present & 0.006 \\
3 & 37.5 & Nil & Nil & 0.16 \\
\hline
\end{tabular}

${ }^{T}$ Group 1: rice straw + mixed concentrate; Group 2: rice straw + mixed concentrate $+50 \%$ leucaena; Group 3: rice straw + mixed concentrate + gradually increased amount of leucaena from $10 \%$ to $50 \%$ level (4 days for each level).

\section{Conclusion}

This study has shown that gradual introduction of leucaena leaf into the diet of sheep can prevent the appearance of symptoms of mimosine toxicity in the sheep. This suggests that rumen microflora have adapted to the changes in dietary composition through the slow introduction of leucaena. This has far-reaching implications for how leucaena can be used in the diets of animals, especially in cut-and-carry systems.

\section{Acknowledgments}

The authors thank all teaching and laboratory staff from the Department of Physiology and Biochemistry, University of Veterinary Science. The IAEA Project, MYA/5/011 provided chemicals for this experiment. We also thank Prof. Ted Wolfe for guidelines and advice for this manuscript.

\section{References}

Aung Aung. 2007. Feeding of leucaena mimosine on small ruminants: investigation on the control of its toxicity in small ruminants. Ph.D. Thesis. Georg-August-University of Göttingen, Germany.
Hegarty MP; Schinkel PG; Court TD. 1964. Reaction of sheep to the consumption of Leucaena glauca Benth., its toxic principle mimosine. Australian Journal of Agricultural Research 15:153-167.

Jones RJ; Blunt CG; Nurnberg I. 1978. Toxicity of Leucaena leucocephala. The effect of iodine, mineral supplementation on penned steers fed a sole diet of leucaena. Australian Veterinary Journal 54:387-392.

Jones RJ; Hegarty MP. 1984. The effect of different proportions of Leucaena leucocephala in the diet of cattle on growth, feed intake, thyroid function and urinary excretion of 3-hydroxy,4-(1H) pyridone. Australian Journal of Agricultural Research 35:317-325.

Khin Htay Myint. 2005. Evaluation of Leucaena leucocephala and Ziziphus mauritiana as sources of tannin and their interference to the nitrogen utilization in goat. M.V.Sc. Thesis. University of Veterinary Science, Yezin, Myanmar.

Ni Ni Maw; Khin San Mu; Aung Aung; Moe Thida Htun. 2004. Proceedings of the annual research conference held in Yangon on June 28-30, 2004. Livestock and Fishery Science. Myanmar Academy of Agriculture, Forestry, Livestock and Fishery Sciences. p. 163-175.

Wink Phyo Thu. 2010. Study on the effect of silage making on the content of tannin and mimosine in Leucaena leucocephala. M.V.Sc. Thesis. University of Veterinary Science, Yezin, Myanmar.

\section{(c) $\$(0)$}

Tropical Grasslands-Forrajes Tropicales is an open-access journal published by Centro Internacional de Agricultura Tropical (CIAT). This work is licensed under a Creative Commons Attribution-NonCommercial-ShareAlike 3.0 Unported License. To view a copy of this license, visit http://creativecommons.org/licenses/by-nc-sa/3.0/. 
Aung Aung; Lwin Naing Oo; Moe Thida Htun; Mar Mar Kyi; Tin Ngwe. 2013. Development of leucaena mimosine-degrading bacteria in the rumen of sheep in Myanmar. Tropical Grasslands - Forrajes Tropicales $1: 48-49$.

DOI: $\underline{10.17138 / T G F T(1) 48-49}$

This paper was presented at the $22^{\text {nd }}$ International Grassland Congress, Sydney, Australia, 15-19 September 2013. Its publication in Tropical Grasslands - Forrajes Tropicales is the result of a co-publication agreement with the IGC 2013 Organizing Committee. Except for adjustments to the journal's style and format, the text is essentially the same as that published in: Michalk LD; Millar GD; Badgery WB; Broadfoot KM, eds. 2013. Revitalising Grasslands to Sustain our Communities. Proceedings of the $\mathbf{2 2}^{\text {nd }}$ International Grassland Congress, Sydney, Australia, 2013. New South Wales Department of Primary Industries, Orange, NSW, Australia. p. 235-236. 